\title{
neofilolog
}

\author{
Czasopismo Polskiego Towarzystwa Neofilologicznego \\ ISSN 1429-2173, 2019, NR 52/1, 89-101 \\ http://dx.doi.org/10.14746/n.2019.52.1.8 \\ http://poltowneo.org/
}

\author{
Paweł Scheffler \\ Adam Mickiewicz University in Poznań \\ https://orcid.org/0000-0002-8130-8095 \\ spawel@wa.amu.edu.pl
}

Wolfgang Butzkamm

RWTH Aachen University

https://orcid.org/0000-0001-5734-2886

wbutzkamm@web.de

\section{PATTERN PRACTICE REVISITED: FROM SYNTAX TO SENSE AND POSITIVE EMOTIONS}

\begin{abstract}
For many second and foreign language learners, the goal of language instruction is fluent oral performance. Such performance can be achieved if the mechanisms underlying L2 performance have been automatized. It is generally recognized that promoting automaticity in the classroom requires massive repetition and consistent practice, which, however, need to correspond to conditions of use in order for transfer into real speech to take place. It is also often acknowledged that meeting these requirements in classroom instruction is very difficult as traditional repetitive practice activities often take time away from communicative language use and fail to induce positive emotions in learners. In this article, we take a fresh look at the theory behind, and the implementation of, pattern practice. We begin by arguing that it is construction grammar that provides a theoretical foundation for pattern practice. We also demonstrate that monolingual drills in the audiolingual method marginalized meaning and were often mechanical. We then present bilingual drills as an alternative exercise type which facilitates pattern recognition, oral repetition and focus on meaning. We show that referring to the native language makes it possible to localize and individualize the examples used and to induce positive emotions in the process. Finally, we discuss communicative drills and use transcripts
\end{abstract}


of classroom interaction to demonstrate that repetitive practice, communication and positive emotions can all be combined.

Keywords: pattern practice, bilingual drills, native language in learning English as a foreign language, positive emotions

Słowa kluczowe: gramatyczne dryle tłumaczeniowe, język ojczysty w nauce języka angielskiego, pozytywne emocje

\section{Traditional pattern practice: the tendency to neglect meaning}

According to Kelly (1969: 101), exercises that tried to exploit the productive potential of sentence structures appeared in Renaissance textbooks but probably date back to classical times. One of the authors unearthed pattern drills as part of conversation practice in a German-Latin phrasebook of the tenth century. A knight talks to his servant:
Gip mir min ros.
(Give me my horse)
Gip mir minan scilt.
(Give me my shield)
Gip mir min sper.
(Give me my spear)
Gip mir mine hantscuoha. (Give me my gloves)
Etc.

This repetitive interplay between what is constant and what varies is characteristic of pattern drill.

Exercises involving oral manipulation of grammatical structures became widely known and used in the 1950s and 60s in the audiolingual method, of which they were a 'distinctive feature' (Richards, Rodgers, 2001: 60). The audiolingual method appealed to structuralist linguistic theory for its description of language and to behaviourism for its learning theory. This resulted in grammatical structures being first introduced to foreign language (FL) learners in dialogues and then practised orally through drills which required, for example, repetition, replacement, restatement or completion. Hardly any grammatical explanations were given in the process. Such instruction was supposed to lead to the development of automatic L2 verbal behaviour consisting of appropriate stimulus-response sequences. The long term objective of the method was for learners to achieve L2 language proficiency not far from that of its native speakers.

Pattern drills were recommended in order for key constructions to be identified and encountered often enough to take root in the learners' competence. The audiolingualists argued that the slots in the patterns could be filled 
with any number of words, simply to avoid the monotony of repetition. Words (and their meanings!) were down played. Language teaching echoed the mainstream linguistics of the time, as criticised by Givón (1979: 86): "The acquisition of 'structure' was studied without the acquisition of 'function' and in isolation from the communicative and interactive environment in which child language development takes place".

This tendency in traditional pattern practice to underplay the role of meaning was certainly counterproductive. If, as for example Tomasello (2003) argues, language structure emerges from language use, meaning is ever-present and decisive. The combinatorics is a means to an end, it is a way of expressing new ideas. Natural language acquisition is always meaning-oriented and lexically dependent. So meaning considerations should come first. It follows that sentence variations must be constructed as sense variations, and must be experienced as such.

To sum up: In traditional pattern drills, any lexical changes will do that fit the sentence pattern. But it is precisely these lexical changes that convey new ideas and bring in the real world. If they are considered as unimportant, pattern drills can easily turn into a self-contained language game, a mere manipulation of forms, with little relation to the world of ideas, events and emotions. It is not surprising, then, that faced with language instruction of this type "many found the experience of studying through audiolingual procedures to be boring and unsatisfying" (Richards, Rodgers, 2001: 65). As Grittner (1969: 203), a school inspector form Wisconsin points out, the misuse of pattern drills was at least partly responsible for learners' dissatisfaction:

Of all the elements which constitute the new American Method, the pattern drill appears to be most widely misunderstood. In the hands of a knowledgeable teacher, such drills are capable of producing an exhilarating classroom atmosphere with students sitting on the edge of their chairs listening intently for their cues and responding instantly when called upon. However, when used by a teacher who is not aware of the function and purpose of this type of drill, the results can be as stultifying as the choral chanting of verb conjugations and noun declensions.

Learners' dissatisfaction, in addition to theoretical criticism, was certainly an important reason for the decline of audiolingualism.

\section{Rules versus patterns}

Behaviourist accounts of language learning were abandoned in favour of mentalist approaches which appealed to linguistic rules. The development of linguistic competence meant the acquisition of an abstract system of rules. However, this view has been challenged in usage-based approaches to both first 
and second language acquisition (e.g. Roehr-Brackin, 2014; Tomasello, 2003). A central tenet of usage-based approaches is that there are no "empty rules devoid of semantic content or communicative function" (Tomasello, 2003: 100). Under this view, it is not rules that are acquired but linguistic constructions. Learners start with specific exemplars, then develop item-based schemas and finally end up with abstract linguistic constructions. Both L1 and L2 linguistic competence can thus be seen as an inventory of constructions of different degrees of generality (e.g. Tomasello, 2003: 99). Further, when producing grammatical utterances speakers do not rely on rules but "analogize from previous utterances" (Larsen-Freeman, 2015: 273).

Assuming that the above conceptualization of linguistic competence is correct, learners seem to be facing two main tasks. First, they need to build up an inventory of constructions. Second, they need to learn how to deploy these constructions, which involves retrieval and grammatically appropriate integration of previously learnt constructions (e.g. Dąbrowska, 2004: 22-23). Ideally, the processes of retrieval and integration should proceed with automatic fluency, which can be defined as "the smooth and rapid production of utterances, without undue hesitation and pauses" (Gatbonton, Segalowitz, 2005: 326).

As Segalowitz (2010: 75) explains, "it is (...) generally accepted that L2 mastery and high levels of utterance fluency require automatization, and a major route to automaticity is repetition". Repetition here refers to both "input repetition", i.e. "frequent exposure", and "output repetition", that is "massive production practice". However, not any massive production practice will do. Successful memory retrieval at the time of communication can occur if the cognitive and perceptual processes involved in it correspond to those that took place at the time of learning. This is the principle of transfer appropriate processing (e.g. Segalowitz, 2010).

\section{Thinking, learning and emotions}

It seems, then, that FL learners need activities which combine four things: (1) pattern recognition, (2) repetition to achieve automatic fluency, (3) meanings, ideas and communication and (4) positive emotions. Using traditional pattern practice activities to achieve this may be very difficult because, as Segalowitz (2003: 402) says, and as we demonstrated above, such activities neglect meaning and "tend to operate in a way that may undermine the goals of communicative orientations to language teaching". They also induce negative emotions in learners, as was the case in the audiolingual method. However, pattern practice should not be equated with audiolingual pattern drills. As the following sections show, meaningful bilingual drills, i.e. those that use mother tongue cues 
and "require the student to process meaning", and monolingual communicative drills, that is those that "require conveying actual content unknown to the hearer" (DeKeyser, 1998: 50), can stimulate positive emotions in the classroom.

While the disruptive effects of negative emotions (mostly anxiety) on foreign language learning are well documented (for example, Dewaele, MacIntyre, 2014), much less is known about the contribution of positive emotions like joy, interest or contentment to the process. However, an examination of the effects of positive emotions on people's thinking in general reveals that positive affect clearly broadens cognition. Fredrickson (2003: 332-333), summarising the results of a series of studies by Alice Isen and her colleagues states that they demonstrate that "when people feel good, their thinking becomes more creative, integrative, flexible and open to information". Fredrickson's (2003: 332) own experiments in which emotions were induced by evocative film clips also confirm that those experiencing positive emotions exhibit "a broadened pattern of thinking". In relation to foreign language learning, this kind of ability to integrate information may facilitate pattern recognition and the acquisition of grammatical constructions.

Given the facilitative effect of positive emotions on people's thinking, stimulating them seems to be an important task that (foreign language) teachers should engage in. In Fredrickson's (2003: 332) experiment, the positive emotion of joy was elicited by having the participants watch a film clip showing "a herd of playful penguins waddling and sliding on the ice". There are many other options, though. Maclntyre and Gregersen (2012: 209) discuss teacher immediacy as a means of inducing positive emotions. They see immediacy as consisting of "nonlinguistic approach behaviours" (for example, reducing physical distance, using gestures, smiling, using vocal variety and maintaining eye contact during interaction) and language that "signals availability for communication", for example through using personal examples and humour. Many of the features of immediacy listed by Maclntyre and Gregersen (2012: 209) are included in pattern practice as we present it below.

\section{Meaningful bilingual drills}

So how can we provide learners with massive input and output repetition so that constructions are identified and L2 performance is automatized? And how can we ensure that learners experience positive emotions in the process? We would like to propose that two types of drills, meaningful bilingual drills and monolingual communicative drills, can go a long way towards achieving this goal.

New constructions must not remain encapsulated in the basic texts, which provide initial input for learners, but must be extracted, recombined 
and varied in order to fit new situations and convey new ideas: What shall we do with the drunken sailor? This sentence, though useless for the purpose of communication, may easily lead to $\Rightarrow>$ What shall I do with my hair? $\Rightarrow>$ What shall I do with my wife? =>What shall I do with my life? With the same construction, we not only build new sentences but think novel thoughts which most of the time carry affective meanings. This is the key for a new understanding of pattern practice and our attempts at revitalising it.

Bilingual drills are a type of pattern practice in which mother tongue prompts are used instead of monolingual substitutions, extensions or transformations (Butzkamm, Caldwell 2009; Scheffler 2013, 2016). This way we start with ideas and feelings (not forms plus "fillers"), which have to be put into foreign language words, just like in normal speech. It makes all the difference: We have an idea in mind that we put into words. However, a stimulus sentence coming from the teacher is not our own idea. That's why a drill phase can only be complete if students get an opportunity to create their own sentences and messages. The teacher begins with a bilingual phase, and when the students take over, the mother tongue drops away and the drill becomes monolingual. Thus the drills are psychologically real in the sense that an idea is formed in the learners' minds which they try to express in words, foreign language words.

Bilingual drills work best if the learners are not distracted away by the actual L1 words and how they are put together, but see through to the meanings, which in turn trigger their FL response. This is what seems to happen in simultaneous interpreting, where a process of deverbalisation is postulated (e.g. Seleskovitch, 1975). The conference interpreter gets the message and restates it in another language. This is also how Dodson explains bilingual pattern drills: "When the teacher gives a mother tongue stimulus, a concept is conjured up in the learner's mind. It is this concept, not the mother tongue words, which the pupil expresses in foreign-language terms" (Dodson, 1967: 91). Nevertheless, interference errors that echo the mother tongue stimulus do occur, but we think that the profits of mother tongue cues outweigh the costs.

\section{Distinctive features of mother tongue prompts}

We will now draw on examples from our project documenting the implementation of bilingual pattern practice in teaching English as a foreign language. All the examples provided here have been used in German and Polish classrooms. Where actual exchanges were recorded and transcribed, references are provided to identify the learners that participated in them. We start a typical exercise with a basic sentence which comes from a familiar dialogue or text (here taken from the spiritual song Kumbaya). The sentence exemplifies 
a pattern whose functions are completely understood. Often an idiomatic translation will do to start the drill:

Teacher (holds hand behind ear):

Listen:

Da singt einer.

Da spricht einer.

Da spricht einer Türkisch.
Student:

Someone's singing.

Someone's speaking.

Someone's speaking Turkish.

We always begin with easy substitutions so that the students can respond readily and accurately. At this stage, we often work on students' pronunciation, making them repeat a sentence even if it was a grammatically correct response. Students should get a feel for the rhythm of a construction. As the class proceeds through a drill, we focus more on content without, of course, going beyond the interest of the learners.

Following simple substitutions like in the example above, we start to explore the semantic range of the pattern. However, it is not the sheer number of possible variations but the various topics and themes that make the difference. Students need help to change the sentences with a view to applying them later to new situations that are personally relevant for them. The idea is to turn a phrase taken from a basic situation - let's say 'What about my friend' - into a productive sentence pattern, and, at the same time, explore its communicative potential for the students.

Teacher:

Was ist (wie wär's) mit meinem Freund?

Was ist mit unserem Präsidenten?

Was ist mit unserer Hausaufgabe?

Was ist mit Mathe?

Wie wär's mit 'ner Pizza?
Student:

What about my friend?

What about our president?

What about our homework?

What about maths?

What about a pizza?

We have found such transitions easy because the students immediately see which part of the pattern sentence remains unchanged. But notice the semantic leaps, especially from "president" to "homework" - the students can see the semantic range of the new phrase and its applicability to a variety of situations. Pragmatic leaps - as in the pizza sentence - are also possible. When called upon to make up their own sentences some students easily make these semantic and pragmatic leaps and change topics, whereas others keep within given domains, for instance school subjects or food items, and do not apply them unhesitatingly by themselves to really new situations. 
Monolingual drills have been criticised for their topic-neutrality and lack of content interest. Bilingual drills make it possible for the teacher to personalise, individualise or localise at least some of his/her mother tongue cues. Here is an example (German grammar school, 2nd year English) where the teacher alludes to a general election in Germany in 2005 (Schröder vs. Merkel). The class had been practising somebody needs somebody or something.

Teacher:

Angie (Merkel) braucht Hilfe.

Sie braucht Hilfe von ihren Freunden.

Angie braucht Hilfe von den Wählern. Say: voters.

Herr Schröder braucht auch Wähler.

Sie alle brauchen unsere Stimmen. Say: votes.
Student:

Angie needs help.

She needs help from her friends.

Angie needs help from the voters.

Herr Schröder needs voters, too.

They all need our votes.

This distinct focus on meaning would be impossible without L1 cues, which shows that the controversy about the use or non-use of the students' native language cannot be solved with the banal advice to use it "judiciously".

Finally, mother tongue prompts also make it possible for the teacher to add some light-heartedness to language practice by drawing upon familiar humorous content. The following examples come from a set of sentences we have used to practise the conditional construction. The first two are taken from the song If you were a sailboat by Katie Melua, number three and four are a development of the theme and the last two allude to a humorous saying and a song by Kasia Klich. All of them are invariably enjoyed by the students.

If you were a sailboat, I would sail you to the shore.

If you were a book, I would read you every night.

If you were a house, I would live in you all my life.

If you were a rocket, I would fly you to the moon.

If you were a car, I would take you to the garage.

If you were a car, I would exchange you for a new model.

\section{The transition to communication}

The stage is set for communication when the students are asked to make up their own sentences. When they do this, most of them are not performing language operations in a void. This transition to a content-oriented monolingual endphase is a major feature of bilingual drills as recommended here. Admittedly, some students will decide to play it safe and give easy or insipid examples, but others will feel tempted to vie with the teacher, take risks and also produce 'loaded' sentences. The teacher may briefly react to some of these sentences. That way the drill can become semi-communicative. The beginnings are modest: 
Pattern practice revisited: From syntax to sense and positive emotions

Teacher:

Etwas stimmt nicht mit dieser Welt.

Etwas stimmt nicht mit meinem Computer.

Etwas stimmt nicht mit unserem Lehrer.

Now make your own English sentences.
Student:

There's something wrong with this world. There's something wrong with my computer. There's something wrong with our teacher.

Here is what the students (10-year-old German learners of English, primary school) produced:

Student: There's something wrong with my CD player.

Student: There's something wrong with my pink elephant.

Student: There's something wrong with my book.

Teacher: Which book?

Student: My exercise book.

The final step in the sequence of drills that we have used in our classrooms involves using a given pattern to convey or obtain new information. Learners try out various constructions and vocabulary items and at the same time talk freely about their own experience. This means that we switch from meaningful to communicative drills.

As the transcripts of classroom interaction included below show, simultaneously focusing on form and content is something that learners can cope with quite well. For us, this is evidence that communicative drills make it possible to combine communication and repetitive practice. Further, it is also evident from the data that practising grammatical constructions may induce the positive emotions of interest and enjoyment.

The first excerpt comes from a Polish secondary school class in which bilingual drills on conditional sentences were followed by an exercise in which the students were asked to complete sentences like If I could fly ... . When the completed sentences were presented the teacher asked follow-up questions or commented on them, for example:

S: If I could fly I wouldn't use any other means of transport.

T: Do you think that would be useful in P? Being able to fly?

S: Yes, I'm sure it would be.

T: Why?

S: Why? Because in P. there are ... I don't have any car so I have to use public transport, public means of transport, and I have to wait for them, I have to buy a ticket, so if I could fly I wouldn't have to ...

T: You wouldn't have to do that. And you wouldn't waste time in traffic jams. 
In another secondary school class in Poland, following the drills on questions in the simple past tense the students were asked to prepare one question each for the teacher. They were also encouraged to ask spontaneous follow-up questions depending on the teacher's answers. This led to exchanges like the one below:

S: Did you go abroad last summer?

T: No, last summer I didn't go abroad.

$S$ : So you stayed here. And, maybe, did you spend time with your family?

T: Yes I did. I spent time with my family, exactly.

S: And, did you had ... did you have a good time with them?

$T$ : Yes I did, we went to the seaside.

S: Great.

On yet another occasion, when the students invented their own sentences, one of the authors asked two groups of secondary school Polish learners of English to decide if the sentences were true or false for them, i.e. whether they really meant what they said. Here is an example of the conversations that followed the drills on the present perfect tense:

S1: I have played the piano for one month.

$T:$ Can anyone tell us?

A few students in chorus: false.

T: False?

S1: True!

T: OK, so you have played the piano for a month.

S1: Yes.

T: Aha. So you took it up one month ago. And...do you like it? Is it hard work?

S1: Yes, and I don't have some practice in some school, but my dad teach me.

T: Aha, so your dad teaches you. OK, so how many lessons from your dad have you had so far? Cate zdanie, whole sentence. Think about it, it was only a month ago that you started, so you should remember, more or less, how many lessons you have had so far.

S1: I've had about six lessons.

T: So you're a beginner.

S1: Yes.

T: Do you play any other musical instruments?

S1: No, I don't.

T: But in your family, is your dad a musician?

S1: No, but it's his passion.

T: That is his passion. So, I mean, he teaches you so obviously he can play the piano quite well. 
S1: Yes.

T: OK, is it a good idea to be taught something by one's parents? Anyone. You know, do parents make good teachers?

S2: Yes.

T: They do?

S2: Yes, because they are the best learners....best teachers for their childs.

T: For their children. They are the best teachers for their children.

S3: They know us. They know how to learn us.... how to teach.

T: They know how to teach you. Okay.

(Unpublished data)

T: What is your sentence? (addressing a student)

S1: I have never seen an elephant.

T: An interesting example. What do you think?

S2: In my opinion, this .... this may be false because .... M .... isn't poor person.

T: And she keeps an elephant at home?

S2: No .... no, no, elephants in home [laughter] ... this is ...

T: As a pet.

S2: No, [laughter] outside.

T: Outside, in the garden, you mean.

S2: Possibly.

T: OK. $M$, so do you keep an elephant in the garden?

S1: No, I don't. But I've seen a few in my life.

T: You have seen a few elephants in your life.

S1: In zoo.

T: In a zoo. Aha, so the sentence is false. How many elephants have you seen in your life?

S1: I think I could have seen about ten elephants in my life.

T: So quite a few elephants.

S1: But I'm older than the rest of our group, so I am more experienced.

T: Very, very interesting.

(Scheffler, 2016: 259)

As the last two transcripts above demonstrate, the learners were able to repeatedly produce the relevant constructions to express whatever personal meanings they wanted. They were able to relate to their personal experience and, as the instances of laughter in the last transcript indicate, enjoyed the exchanges. During the conversations, they were also exposed to numerous instances of the conditional provided by the teacher and other learners, that is, they were exposed to large amounts of repetitive yet meaningful input. Finally, the teacher used a number of opportunities to provide corrective feedback in the form of recasts. 


\section{Conclusion}

It has been recommended that drills "should be discarded from instructional practice" because they are not effective (Wong, VanPatten, 2003: 403). Drills have been described as boring and demotivating (Segalowitz, 2003: 402). However, in these descriptions the term 'drills' is used to mean 'mechanical drills'. It is important, as DeKeyser (2007:11) points out, that all drills should not be equated with mechanical drills. If this is done, the criticism levelled at mechanical drills is extended to the other types, which then become "guilty by association".

We see drills as only one of the components of the overall FL instruction process. With them it is possible to go beyond the mere manipulation of structures and manipulate ideas instead. New words embedded in a familiar construction can generate new thoughts and situations. Positive emotions can be aroused when learners are given the freedom to express themselves and to interact with the teacher and the other students. This change of focus is needed to bridge the gap between drill and discourse. Ideally, a balance should be achieved between meaningful/communicative drills and purely meaningoriented activities in which learners simply experience an L2 or interact in it without consciously focusing on any pre-determined linguistic elements. However, given the time constraints applying to a typical L2 classroom, it seems that more classroom time could be devoted to controlled practice, with additional L2 exposure and interaction taking place outside of it.

This paper is based on long-term trialling and learner observation in a variety of classrooms where numerous learners have achieved high levels of language ability. Hopefully, our examples are sufficiently provocative to stimulate future research and experimentation by teachers and researchers. We strongly believe that bilingual and monolingual drills presented here should become known, tried out and tested more widely than heretofore.

\section{REFERENCES}

Butzkamm W., Caldwell J.A.W. (2009), The bilingual reform: A paradigm shift in foreign language teaching. Tübingen: Gunter Narr Verlag.

Dąbrowska E. (2004), Language, mind and brain. Edinburgh: Edinburgh University Press.

DeKeyser R.M. (1998), Beyond focus on form: Cognitive perspectives on learning and practising second language grammar (in) Doughty C., Williams J. (eds.), Focus on form in classroom second language acquisition. Cambridge: Cambridge University Press, pp. 42-63. 
DeKeyser R.M. (2007), Introduction: Situating the concept of practice (in) DeKeyser R. (ed.), Practice in a second language. Cambridge: Cambridge University Press, pp. 1-18.

Dewaele J.M., Maclntyre P.D. (2014), The two faces of Janus? Anxiety and enjoyment in the foreign language classroom (in) "Studies in Second Language Learning and Teaching" No 4(2), pp. 237-274.

Dodson C.J. (1967), Language teaching and the bilingual method. London: Pitman. Fredrickson B. L. (2003), The value of positive emotions (in) "American Scientist" No 91(4), pp. 330-335.

Gatbonton E., Segalowitz N. (2005), Rethinking communicative language teaching: A focus on access to fluency (in) "The Canadian Modern Language Review" No 61, pp. 325-353.

Givón T. (1979), On understanding grammar. New York: Academic Press. Grittner F. (1969), Teaching foreign languages. New York: Harper and Row. Kelly L.G. (1969), 25 centuries of language teaching: An inquiry into the science, art, and development of language teaching methodology: 500 B.C. -1969 . Rowley: Newbury House.

Larsen-Freeman D. (2015), Research into practice: Grammar learning and teaching (in) "Language Teaching" No 48, pp. 263-280.

MacIntyre P.D., Gregersen T. (2012), Emotions that facilitate language learning: The positive-broadening power of the imagination (in) "Studies in Second Language Learning and Teaching" No 2(2), pp. 193-213.

Richards J.C., Rodgers T.S. (2001), Approaches and methods in language teaching. Cambridge: Cambridge University Press.

Roehr-Brackin K. (2014), Explicit knowledge and processes from a usage-based perspective: the developmental trajectory of and instructed $L 2$ learner (in) "Language Learning" No 64, pp. 771-808.

Scheffler P. (2013), Gramatyczne dryle tłumaczeniowe w nauczaniu języka angielskiego (in) „Języki Obce w Szkole” No 1/2013, pp. 82-87.

Scheffler P. (2016), Implementing bilingual pattern practice (in) "RELC Journal" 47(2), pp. 253-261.

Seleskovitch D. (1975), Langages, langues et memoire. Paris: Lettres Modernes.

Segalowitz N. (2003), Automaticity and second languages (in) Doughty C., M.

Long $\mathrm{M}$. (eds.), The handbook of second language acquisition. Malden: Blackwell, pp. 382-408.

Segalowitz N. (2010), Cognitive bases of second language fluency. New York: Routledge. Tomasello M. (2003), Constructing a language: A usage-based theory of language acquisition. Cambridge, MA: Harvard University Press.

Wong W., VanPatten B. (2003), The evidence is IN: Drills are OUT (in) "Foreign Language Annals" No 36, pp. 403-24. 